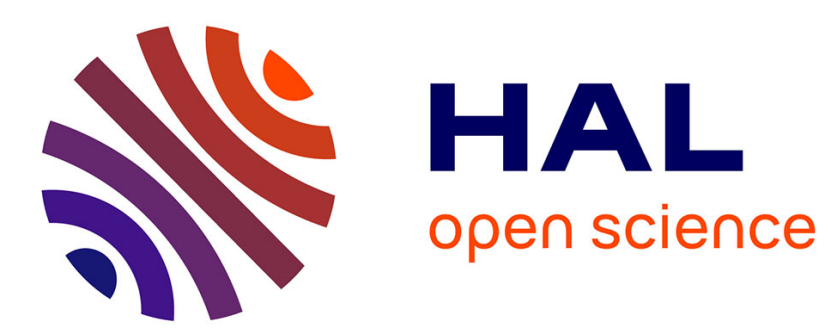

\title{
Corruption and governance in Central Africa: an analysis of public and regional drivers of corruption
}

Stéphane Goutte, Thomas Péran, Thomas Porcher

\section{To cite this version:}

Stéphane Goutte, Thomas Péran, Thomas Porcher. Corruption and governance in Central Africa: an analysis of public and regional drivers of corruption. 2021. halshs-03169700

\author{
HAL Id: halshs-03169700 \\ https://shs.hal.science/halshs-03169700 \\ Preprint submitted on 15 Mar 2021
}

HAL is a multi-disciplinary open access archive for the deposit and dissemination of scientific research documents, whether they are published or not. The documents may come from teaching and research institutions in France or abroad, or from public or private research centers.
L'archive ouverte pluridisciplinaire HAL, est destinée au dépôt et à la diffusion de documents scientifiques de niveau recherche, publiés ou non, émanant des établissements d'enseignement et de recherche français ou étrangers, des laboratoires publics ou privés. 


\title{
Corruption and governance in Central Africa: an analysis of public and regional drivers of corruption
}

\author{
Stéphane Goutte*, Thomas Péran ${ }^{* *}$ and Thomas Porcher ${ }^{* * *}$
}

\begin{abstract}
This article seeks to highlight in more depth the public levers of action in the implementation of anticorruption policies within the countries among the Central Africa region. Using non-supervised statistical method, we first study the profile of the countries concerned (institutional, social, entrepreneurial, etc.), then secondly, we analyze the impact of public measures on the extent of corruption at the national level. We manage to demonstrate that there is a common and standard subregional political program intended for public decision-makers, regardless of the degree of heterogeneity of national structures.
\end{abstract}

JEL classification: D73, O21, H11

Keywords: Corruption, Datamining, Cluster, Political program, Central Africa

\footnotetext{
* Université Paris-Saclay (CEMOTEV), France. Corresponding author: stephane.goutte@uvsq.fr

** Professor at Lusail University (Qatar), Research Fellow at Université de Paris (Centre Maurice Hauriou)

*** Associate Professor at PSB Paris School of Business
} 


\section{Introduction}

The traditional scientific literature distinguishes three types of corruption: petty corruption, grand corruption and political corruption. With regard to petty corruption, that is to say the corruption of individual citizens ${ }^{1}$, there is a relatively strong consensus on the apprehension of the corruptive phenomenon by the "theory of the fraud triangle" developed by the American sociologist Cressey (1950). According to this theory, any act of corruption stems from a three-dimensional environment comprising the following elements: opportunity, motivation and rationalization. The advantage of such a theoretical scheme is that it makes it possible to take into account vectors of corruption emanating from both individual-social and political structures, while many other theories oppose them.

Going straight forward in the same direction, the detailed understanding of the mechanisms inherent in grand corruption is articulated very well with this same fraud triangle theory, provided that one weighs in a completely different way the weight of the three elements which make it up: the mercantile and profitable motivation then plays a multiplier role on the opportunity and rationalization. Of course, it is always possible to criticize this multidimensional and static approach in the in-depth analysis of corruption, arguing that the realities on the ground hardly accommodate theoretical and generic schemes. Moreover, many critics claim that such synthetic representations of the phenomenon of corruption are far too simplistic to account for an evolving and real phenomenon that knows no borders (Schuchter and Levi, 2015).

As far as political corruption is concerned, no theoretical scheme can satisfactorily capture it. Its definition is well known since it is a question of analysing it as taking advantage of a power relationship 2 for the purpose of obtaining exclusive gain. Usually, an individual or a group of individuals with governmental functions arrogates to themselves freedoms, at least partially extraneous to the interests of citizens and the common good. But the questions of the doctrine in the matter relate mainly to the factual conditions which make that each interstice of the public political life is likely to facilitate the corruptive phenomenon (Ni et al., 2019).

Thus, by having a good knowledge of the scientific literature, but also of the realities on the ground, it is possible to put in place mechanisms to prevent corruption risks, both in the private and public spheres. This is for example the objective of the international standard ISO 37001 "Anti-Bribery Management System"3. By using modern managerial techniques, such as the implementation of sectoral anti-corruption policies or the creation of a single anti-corruption referent independent of the organization's compliance function, a reduction in fraudulent acts is automatically obtained by strengthening the prevention component. The establishment of an internal whistleblowing mechanism is a similar preventive measure advised by such professional standards.

But with regard to political corruption, due to the State's vocation for economic performance, that is to say the proper functioning of public services as well as the sound management of public

\footnotetext{
${ }^{1}$ It can be petty corruption within the private associative and professional spheres, as well as individual behaviours from State officials.

2 In this case, a political position of a governmental kind.

${ }^{3}$ See https://www.iso.org/iso-37001-anti-bribery-management.html.
} 
finances in terms of indebtedness, such generic preventive approaches are unsuitable for achieving a constant and effective reduction in corruption. First of all, rationalization is not of paramount importance in the State machine where the qualification and social status of individuals are relatively homogeneous. Moreover, the opportunity, that is to say the probability of occurrence of the corrupt act is abnormally high. The entire State apparatus must be seen as abnormally and extremely exposed to the risk of fraud. Preventive and repressive mechanisms, as well as individual morals, condition the commission of fraudulent acts. This is therefore a reversal of the situation from the non-public sphere in which it is possible to draw up a classification of jobs particularly exposed to the risk of fraud. It consequently seems that any attempt to control the risk of corruption, and then to reduce corruptive acts, can only be undertaken by taking into account the economic policy aggregates and the individualization of each of them (Hessami, 2014; Smith, 2016). The objective of this article is therefore to exclusively serve such an approach by asking the following question: What are the political levers that make it possible, within an overall State political program, to fight corruption most effectively?

\section{Data}

The application of our methodology and the formulation of our analyses are dedicated to the countries of Central Africa. The choice to limit our study to such a population stems from two main arguments. First, it is quite correct to say that the databases available to researchers concerning the phenomenon of corruption are numerous today. The International Monetary Fund and the World Bank, as well as the largest banking institutions, are the data providers and the interlocutors considered to be the most reliable. But it does not seem appropriate to use in the matter a unique and standardized methodology on a global population of countries, even though it appears that the responses to be given in the context of the fight against corruption are regional in themselves (Becker et al., 2009). Second, while trying to ensure as pure an analysis as possible of what one might call a "common regional grammar" of corruption in Central Africa, it is also important to be able to maintain a high level of observation of national particularisms inside the population of States. Thus, studying the countries of Central Africa has the double advantage of allowing the comparison of countries subject to similar conditions of financial, social, geographical and institutional pressures, while presenting different cultural and political profiles (Andvig, 2008).

Our reasoning is based on the use of the African Development Bank Group (AfDB, 2018) Country Policy and Institutional Assessment (CPIA) database. Produced annually, it has the advantage of providing reliable and rigorous data on aggregates under the direct control of central and decentralized State powers. Thus, each individual among the population studied answers a set of 18 questions grouped into 5 clusters: Economic management, Structural policies, Social inclusion/equity, Governance, Infrastructure and Regional integration. According to the methodology proposed by the $\mathrm{AfDB}$, the higher the national performance in each of the 5 clusters is, the more the States are likely to ensure their economic growth and poverty reduction. In order to preserve the consistency and relevance 
of our calculations, we have used the data covering the 2004-2018 period ${ }^{4}$. In addition, we have taken into account in our analysis major constitutional events that may have a significant impact on the data. Thus, we paid attention to the fact that the Sudanese figures were unique until 2011 and the selfdetermination referendum, then double between 2011 and 2018, since it is now necessary to consider both the Republic of Sudan and the South Sudan. Finally, when we found series that were incomplete or included errors and uncertainties, we decided to remove them from our restated working base 5 .

\section{Methodology and Statistical approach}

We adopt a multivariate analysis. Hierarchical Clustering Analysis (HCA) allows us to highlight similarities (i.e., clusters) in our data. Cluster analysis is a data exploration (mining) tool for dividing a multivariate dataset into "natural" clusters (groups). We use this method to explore whether previously undefined clusters may exist in the dataset. Such a cluster analysis is used when there is reason to believe that the sample units come from an unknown number of distinct populations or subpopulations. There is no a priori definition of populations as our objective is to describe it (i.e., countries) using the observed data.

The use of datamining offers major leverage in many disciplines. The aim is to take advantage of a "non-driven" analytical approach exempted from any reading bias. Mathematical regression analyses are numerous and useful in the economic fields to demonstrate correlations or to predict asset responses to condition variations. However, our paper aims to pattern a classification of similar country profiles based on a quite prominent database without any supervised information or criteria. We aim to identify a statistical structure strictly based on our data. The very use of regression or correlation would give us only the quantification of corresponding results and the parameter impacts on a dependent variable, but would not provide us with a dataset specific structure.

In the agglomerative hierarchical approach, we first define each data point as a cluster and combine existing clusters in each step. We employ Ward's method. This method does not directly define a measure of distance between two points or clusters but is an ANOVA-based approach. Each stage merges the two clusters that generate the smallest increase in the combined error sum of squares, from a one-way univariate ANOVA for each variable, with groups defined by the clusters at that stage of the process. This cluster analysis can be regarded as an analysis of variance problem, instead of using distance metrics or measures of aggregation. This method involves an agglomerative clustering algorithm. Ward's method begins with $n$ clusters of size 1 and continues until all observations are included in a single cluster.

The results of a cluster analysis are summarized in a dendrogram (Figure 1) where distance is plotted on one axis while the sample units are plotted on the other one. The tree shows how sample

\footnotetext{
4 The year 2017 does not appear in the database since from 2016 it was decided to only use bi-annual measurements

5 So, it is with Angola, Cape Verde, Nigeria and the Republic of Congo.
} 
units are combined into clusters. The height of each branching point corresponds to the distance at which two clusters are joined.

Figure 1: Dendrogram

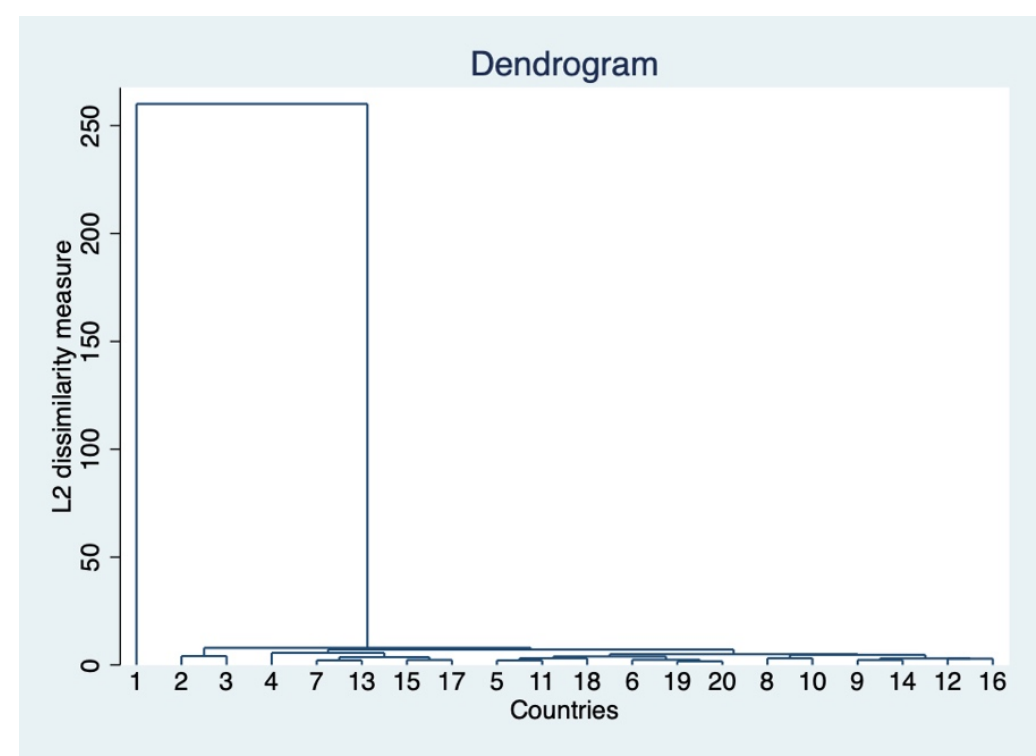

We identify $\mathrm{K}=3$ clusters as the best statistical segmentation of our data. The list of countries in each cluster is reported Table 1 . We state in Table 2 the characterization of each cluster regarding our data. This allows us to identify each cluster regarding our corruption and governance variables.

Table 1: Cluster Segmentation

\begin{tabular}{|c|c|c|c|}
\hline Clusters & 1 & 2 & 3 \\
\hline \multirow{16}{*}{ 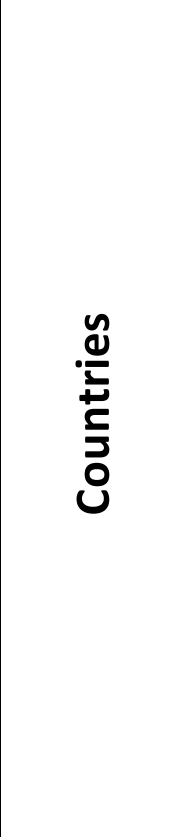 } & Burundi & Benin & Central African Rep, \\
\hline & Chad & Burkina Faso & Comoros \\
\hline & Congo, Dem, Rep, & Cameroon & Eritrea \\
\hline & Djibouti & Cote d'Ivoire & Guinea-Bissau \\
\hline & Gambia & Ethiopia & Somalia \\
\hline & Guinea & Ghana & South Sudan \\
\hline & Liberia & Kenya & Sudan \\
\hline & Madagascar & Lesotho & Zimbabwe \\
\hline & Mauritania & Malawi & \\
\hline & Mozambique & Mali & \\
\hline & Sao Tome \& Principe & Niger & \\
\hline & Sierra Leone & Rwanda & \\
\hline & Togo & Senegal & \\
\hline & & Tanzania & \\
\hline & & Uganda & \\
\hline & & Zambia & \\
\hline
\end{tabular}


Table 2: Characterization of each cluster regarding our data

\begin{tabular}{|l|c|c|c|}
\hline \multicolumn{1}{|c|}{} & \multicolumn{3}{c|}{ Clusters } \\
\cline { 2 - 4 } \multicolumn{1}{|c|}{ Variables } & 1 & 2 & 3 \\
\hline Fiscal Policy & 3,42 & 4,22 & 2,25 \\
\hline Monetary Policy & 3,77 & 4,47 & 2,50 \\
\hline Debt Policy & 2,88 & 4,09 & 2,00 \\
\hline Financial Sector Development & 3,19 & 3,88 & 2,27 \\
\hline Trade Policy & 3,42 & 3,99 & 2,53 \\
\hline Business Regulatory Environment & 3,28 & 3,97 & 2,23 \\
\hline Gender Equality & 3,19 & 3,80 & 2,73 \\
\hline Equity of Public Resource Use & 3,26 & 4,02 & 2,13 \\
\hline Building Human Resources & 3,15 & 4,11 & 2,56 \\
\hline Social Protection and Labor & 2,92 & 3,79 & 2,20 \\
\hline Environmental Policy and Regulations & 3,35 & 4,09 & 2,50 \\
\hline Property Rights and Rule Based Governance & 2,98 & 3,78 & 2,25 \\
\hline Quality of Budgetary and Financial Managmt. & 3,40 & 4,14 & 2,30 \\
\hline Quality of Public Administration & 2,71 & 3,76 & 2,03 \\
\hline Efficiency of Revenue Mobilization & 3,60 & 4,30 & 2,50 \\
\hline Transparency, Accountability and Corruption in Pub. Sector & 2,82 & 3,74 & 1,98 \\
\hline Infrastructure Development & 3,15 & 4,00 & 2,25 \\
\hline Regional Integration & 3,29 & 4,06 & 2,34 \\
\hline Infrastructure and Regional Integration (Cluster E) & 3,22 & 4,03 & 2,30 \\
\hline
\end{tabular}

To identify the main drivers of corruption we provide in Table 3 the OLS regression result.

Table 3: OLS regression results

\begin{tabular}{|c|c|c|c|c|c|}
\hline \multicolumn{6}{|l|}{ Ordinary Least Squares (OLS) } \\
\hline \multicolumn{6}{|l|}{$N=476$} \\
\hline R-squared $=0.75058$ & \multicolumn{2}{|c|}{ Adj $R$-squared $=0.74245$} & & & \\
\hline Wald $(F 15,460)=92.284788$ & \multicolumn{2}{|c|}{$p$-value $=0.0000$} & & & \\
\hline RSS $=77.746681$ & \multicolumn{2}{|c|}{ ESS $=4646.654462$} & \multicolumn{2}{|c|}{ TSS $=4646.654462$} & \\
\hline Corruption. & Coefficient & Std. & Error & t-stat & $p$-value \\
\hline Fiscal Policy & 0.137699 & 0.046395 & 2.9679 & 0.003 & *** \\
\hline Monetary Policy & 0.043418 & 0.045553 & 0.9531 & 0.341 & \\
\hline Debt Policy & 0.054309 & 0.038815 & 1.3992 & 0.162 & \\
\hline Financial Sector Development & -0.160396 & 0.051574 & -3.1100 & 0.002 & $* * *$ \\
\hline Trade Policy & -0.090906 & 0.048759 & -1.8644 & 0.063 & * \\
\hline Business Regulatory Environment & -0.027369 & 0.051081 & -0.5358 & 0.592 & \\
\hline Gender Equality & -0.019180 & 0.049436 & -0.3880 & 0.698 & \\
\hline Equity of Public Resource Use & -0.106691 & 0.052086 & -2.0484 & 0.041 & $* *$ \\
\hline Building Human Resources & -0.032289 & 0.048948 & -0.6596 & 0.510 & \\
\hline Social Protection and Labor & 0.032548 & 0.058735 & 0.5542 & 0.580 & \\
\hline Environmental Policy and Regulations & -0.051858 & 0.050521 & -1.0264 & 0.305 & \\
\hline Property Rights and Rule Based Governance & 0.468675 & 0.053492 & 8.7616 & 0.000 & $* * *$ \\
\hline Quality of Budgetary and Financial Managmt. & 0.284506 & 0.058645 & 4.8513 & 0.000 & $* * *$ \\
\hline Quality of Public Administration & 0.161095 & 0.058943 & 2.7331 & 0.007 & $* * *$ \\
\hline Efficiency of Revenue Mobilization & 0.178834 & 0.048782 & 3.6660 & 0.000 & $* * *$ \\
\hline CONST & 0.193282 & 0.108007 & 1.7895 & 0.074 & * \\
\hline
\end{tabular}

\section{Results and discussion}

The first methodological aspect of our research, through datamining, allows us to shows that, if the countries among Central Africa are clearly heterogeneous with regard to the orientation of their public policies, it is however possible to draw up a triple regional typology (table 1). Considering the 
public institutional point of view, we see in group 2 a verticality of power which, while resulting from the national constitution, leaves room for the expression of political pluralism. In other words, there are checks and balances within State organizations. In the opposite direction, the vertical exercise of power in groups 1 and 3 is the consequence of a factual situation, linked to misappropriation of the regular functioning of public powers or to situations of war and famine.

Concretely, and according to the dominant constitutional theory, the more arbitrary verticality there is in the exercise of power, the more institutional stability is affected. This is reflected in the following three main aspects: frequency of constitutional changes, arbitrary possession of resources derived from taxes or national wealth, concentration of national and local political power in the hands of the same man or the same group of men. The hypothesis we formulated during the preparatory work for this research is therefore verified: while the stability of public authorities is deteriorated, political corruption is facilitated. This is directly demonstrated by the scores attributed to the variables "Quality of Public Administration" (cluster $3=2.03$; cluster $1=2.71$; cluster $2=3.76$ ) and "Transparency, Accountability and Corruption in Public Sector" (cluster $3=1.98$; cluster $1=2.82$; cluster $2=3.74$ ) (table 2).

The second methodological aspect indicates that the different orientations taken by an overall government policy are not equivalent. Thus, the impact of some measures on reducing corruption is massive and immediate, while others have a more contained impact. We can group together two main families of government measures.

First, the variables "Property Rights and Rule Based Governance" and "Quality of Budgetary and Financial Management" have a very significant effect on the state of corruption (Table 3). It is therefore for the leaders to make the political choice to privilege the needs related to freedom and equality, by allowing each citizen to lead a complete professional life in order to rise economically, but also to strictly supervise the expenditure of compulsory levies. It should also be noted that the fiscal policy put in place $^{6}$, another variable closely linked to the equality value, plays a preponderant role.

Next, it appears that the modernity of public and private administrative structures plays a determining role in the level of corruption in a country. The correlation established between corruption and tax policy (Table 3) is as logical as it is obvious. The more universally a population can raise capital through borrowing within the framework of a stable financial economy, the greater the potential for increased income and a better life. In addition, it seems very appropriate to take care of the public administration. In other words, civil servants must have the real operational means to carry out their missions, but must also be subject to modern, coherent and well-deployed managerial, hierarchical and control standards.

\section{Conclusion}

This article provides a better understanding of the levers to be operated in the fight against corruption, through the analysis of national public policies, while trying to identify a regional political

\footnotetext{
${ }^{6}$ Variables "Fiscal Policy" et “Efficiency of Revenue Mobilization".
} 
program at the level of Central Africa. The regionalization of political responses to national problems resulting from corruption is essential, since this alone can allow States to work effectively with international institutions such as the AfDB or the African Union. In addition, the variables highlighted in our study remind political leaders of a principle constantly reaffirmed by international organizations and NGOs working daily in the field: the quartet "prevent, detect, deter, sanction" must become a standard of action to stamp out political corruption.

\section{Acknowledgements}

Our research team would like to thank His Excellency M. Leopold Ismaël Samba, Ambassador plenipotentiary of the Central African Republic to the Swiss Confederation and Dean of African Ambassadors to the United Nations Office in Geneva. His remarks and thoughts based on a field approach have made it possible to ensure that this article is anchored in operational realities.

\section{Appendix A}

\section{References}

African Development Bank Group, 2018. Country Policy and Institutional Assessment. Available at: https://cpia.afdb.org/ (accessed 25 November 2020).

Andvig, J. C., 2008. Corruption in Sub-Saharan Africa and its sources of evidence. Working paper, NUPI, 58 p. http://hdl.handle.net/11250/278183.

Becker, S. O., Egger, P. H. and Seidel, T., 2009. Common political culture: Evidence on regional corruption contagion. European Journal of Political Economy 25 (3), 300-310. https://doi.org/10.1016/j.ejpoleco.2008.12.002.

Cressey, D. R., 1950. The Criminal Violation of Financial Trust. American Sociological Review 15 (6), 738743. https:// doi.org/10.2307/2086606.

Hessami, Z., 2014. Political corruption, public procurement, and budget composition: Theory and evidence from OECD countries. European Journal of Political Economy 34, 372-389. https://doiorg.ezproxy.u-paris.fr/10.1016/j.ejpoleco.2014.02.005.

Ni, W., Sutrisno, S. et al., 2019. Fraud triangle in public procurement: Evidence from Indonesia. Journal of Financial Crime 26 (4), 951-968. https:// doi.org/10.1108/JFC-11-2018-0121. 
Schuchter, A. and Levi, M., 2015. Beyond the fraud triangle: Swiss and Austrian elite fraudsters. Accounting Forum 39 (3), 176-187. https:// doi.org/10.1016/j.accfor.2014.12.001.

Smith, J. D., 2016. US political corruption and firm financial policies. Journal of Financial Economics 121 (2), 350-367. https://doi.org/10.1016/j.jfineco.2015.08.021. 